\title{
Prishtina: Urban Health Related to Air Quality
}

\author{
Bujar BAJÇINOVCI ${ }^{1}$, Mejreme BAJÇINOVCI ${ }^{2 *}$ \\ ${ }^{1}$ University of Prishtina. Faculty of Architecture, FA, Karl Gega p.n, 10000 Prishtina, Kosovo \\ ${ }^{2}$ National Institute of Public Health, Kosovo, Nëna Tereze p.n., Rrethi i Spitalit, 10000 Prishtina, Kosovo
}

\begin{abstract}
Urban health planning is a process with a primary role to protect communities and to use the environment sustainably. In relation to sustainability, the implementation of law reinforcement, urban planning and design can significantly improve the quality of life, particularly in relation to air pollution. Therefore, it is crucial to encourage every activity related to the functioning of a city, which would minimize air pollution. The empirical and conceptual findings from this research propose the necessity of careful driven urban health solutions, derived from power plants and heavy city traffic, regarding the gasoline-diesel powered automobiles which are not supportive to the urban, economic and health objectives. Prishtina, like other cities, must reconsider implementation of a strategy for healing urban health, helped by new developed technologies and environmental focused activities.
\end{abstract}

Keywords - Air quality; energy; morbidity; PM; Prishtina; urban health.

\section{INTRODUCTION}

Air pollution is a global issue and an essential health problem, faced by millions of people all over the world. Surely, among them are the citizens of the city Prishtina, the capital of Kosovo. Originally the pollution comes from factors of different emanations, such as: the coal-fired power plants in vicinity of the city of Prishtina, coal as energy for heating in residential buildings and heavy air pollution emanated from traffic. Furthermore, regarding energy consume, cities are open complex ecosystems and huge organisms, which enduringly transform enormous amount of energy, as well as natural resources. Urban health is a complex and specific phenomenon directly reflected in contemporary life style and economic, social and aesthetic fields. Cities are open, urban integrated systems and huge organisms with specific and complex metabolisms that transform vast amounts of energy, generate huge amounts of waste and emanate a number of specific environmental activities [1]. However, urban and spatial zones are locally and regionally specific, and therefore the air pollution and hazard emanations have specific attributes in each city. Hence, each urban zone requires a functional health framework, which corresponds to the whole urban health city system. Prishtina, like any other city with a fast-growing tendency, has its own specific needs and autochthonous challenges. Thus, when fast growing cities face these challenges, they also face immediate urban obstacles, which have to be illuminated in order to function normally. Ordinary and practically, city challenges should stimulate new solutions strengthened with integrated environmental actions, mainly directed towards public health in order to provide a better and higher quality of life [1]. Urban health related to urban planning determines the healthy areas, ecological urban blocks, and architectural structures that can potentially be part

\footnotetext{
* Corresponding author.

E-mail address: Mejreme.Bajcinovci@uni-pr.edu 
of the contemporary Smart City features. Engineering approach to holistic phenomena is emphasized by the need to create harmony between the need for function and rational ideas displayed for particular situations and environments. The actual practice of linear design is of a single or sequential nature; therefore, this model is currently used mostly for all urban design schemes. We are witnessing an immediate need for addressing social and economic problems while at the same time we are experiencing degradation of the local environment. Proper understanding of resource conservation for future generations consists of the fact that there is an interdependency between us and natural resource requirements, and the empowerment of possible alternatives to preserve the ecosystem for future generations [2]. Furthermore, we have authentic examples of historiography of past civilizations and their disappearance as a phenomenon of emptying the essential resources needed for living [3]. Ergo, approaching and thinking that this phenomenon will happen to another generation rather than the current generation, creates incorrect perception of reality, as the whole ecosystem is in direct interaction and dependence not only currently but also in the future. It is generally known that facilities are users of at least half of the total energy produced in the world, such as: heating, lighting, air conditioning, refrigeration, construction, and industry. "When it comes to cities, even if they occupy roughly $2 \%$ of the Earth's lands, they are responsible for about $70 \%$ of the global greenhouse gas emissions, consuming over $60 \%$ of the total energy produced in the world and generating $70 \%$ of all waste" [4], [5]. The largest percentage of this expenditure is directly interlinked with public health. "The EPA Air Quality Criteria Reports present the criteria for setting acceptable air quality concentrations in the ambient air, outdoor public air space, for PM and five other polluting emissions $\mathrm{SO}_{2}, \mathrm{CO}, \mathrm{NO}_{2}, \mathrm{VOC}$, and lead. The reports review and summarize the extensive scientific data for these criteria pollutants in detail" [6]. "Primary carbonaceous aerosol is emitted from numerous sources including motor vehicle exhaust, residential wood combustion, coal combustion, forest fires, agricultural burning, solid waste incineration, food cooking operations, and road dust. Quantifying the primary contributions from each major emission source category is a prerequisite to formulating an effective control strategy for the reduction of carbonaceous aerosol concentrations" [7]. There is a general consensus that regional and local identity will play an important role in the urban health, with continuity of diversity of culture and ethnological attributes in which local identity and community are maintained. The feeling that we belong to something, to some urban zone, as a part of the whole spatial space, is directly linked to nature wholeness: "how we maintain city attributes, thus are the results of urban health". The new millennium brings special and fundamental situations where the necessity of redefining the new lifestyle is acquired. What will be the reaction of the construction industry to the climate change, greenhouse effect, and use of natural resources? An important segment of Kosovo's policy is reflected in its energy program, which promotes energy efficiency (EE), the implementation of EE measures in the relevant sectors according to the Europe Union objectives. This promotional policy directly affects the economic development, energy saving, increased security of energy supply, and preservation of the environment. Urban health policy is aimed at identifying priority problems. However, health problems can develop very quickly and priorities should be periodically and regularly updated. Moreover, while environmental changes follow developed countries, national priorities should be adapted to global environmental objectives. In addition, determining urban health priorities defines what is urgent or less urgent and important. Thus, it is clear that only a healthy environment, in the broader or narrower sense of the concept of quality of life in the terms of global health actions, may result as an adequate solution. The new contemporary age brings with it a new lifestyle as a result of a number of determining factors, but first and foremost - the development of technology. New urban situation presents a new concept of health value and the necessity for new life habits. The way we 
live is changing. Actually, more than ever we are familiar with the metropolitan urban style, depending on technology in all aspects of our lifestyle, gladly embracing with open arms the metropolitan living challenges, amidst a fast and dense growing population. "The high degree of complexity involved in identifying and quantifying long-range pollution transport, particularly in identifying and characterizing contributions from individual pollution sources, will require new developments in analytical and observational techniques" [8]. According to the World Health Organization in Europe, "The epidemiological and toxicological evidence on the effects of transport related to air pollution on health has increased substantially in recent decades. Although this includes epidemiological and toxicological evidence, it is only a fraction of the total evidence on the effects on health of urban air pollution" [9]. Furthermore, according to the conducted research of air pollution and efficiency of energy, related in emissions of $\mathrm{CO}_{2}$ and Gross Domestic Product, "Kosovo as one of the richest countries with lignite in Europe with $95 \%-97 \%$ of the electric power production from lignite and with $90 \%$ of vehicles over 15 years old, represents one of the regions with the greatest $\mathrm{CO}_{2}$ output per GDP per unit of economic activity. In this relation we must consider the fact that Kosovo is a developing country" [10]. Motor vehicles and especially vehicles above 3.5 Mt have raised their quote permanently each year in the last decades in Kosovo. "Annual carbon dioxide amounts in Kosovo, produced from motor vehicle use is estimated at around 0.8 million tonnes or about $15 \%$ of total carbon dioxide $(5.3 \mathrm{Mt})$ production in 2003, both from transport and electricity generation" [11]. Surely, air pollution can be percepted as a compound of airborne chemicals and particulates active or inert matter of different sizes. Each chemical can lead to emissions alone or in symbiosis with other chemicals, thus, strengthening the effect of air pollution [12]. "The biological effects and transport properties of particulate air-pollution are closely related and depend strongly on the particle size distribution. The size of the particles determines the deposition site and deposition efficiency in the human respiratory system" [13]. To fully understand urban pollution, it is necessary to perceive the economic development background and the key factors which impact the emission of air pollutants [14]. Automobile greenhouse gas and air pollution emissions are estimated to increase in the cities of Kosovo as a consequence of the expanding framework of motor vehicles, and from coal-fired power plants. This study examines the development of air pollution issues and pressures of air pollution which influence the actual state of air quality. Furthermore, it discusses the key effects on human health derived from power plants, heavy city traffic and gasoline-diesel powered automobiles which are hazardous to the urban health, the economy, and environmental objectives. The research also administers an overview of the measures taken to address air pollution emissions. However, the management of the issues of air pollution are still a great burden in relation to sustainability, the implementation of law reinforcement, urban planning, and improvement of the quality of life globally, and especially in Kosovo.

\section{Methods ANd Procedures}

The study presented in this paper analyses the emanations, such as: air pollution from heavy traffic, coal-fired power plants in the vicinity of the city of Prishtina, coal as a source for heating in residential buildings, and identification of feasible opportunities to minimize the health degradation from these sources of pollution. The actual conditions of particulate matters hazard situation, and other atmospheric air pollutants are used as inputs to research air quality model to simulate possible future ambience. With actual emission conditions, the research tends to describe various sources of air pollution based on projections of population (see Fig. 1), production of electricity, migration, mobility, and economic growth. 


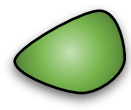

1948

40361 Inhabitants

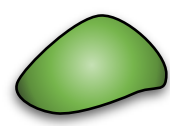

1953

47244

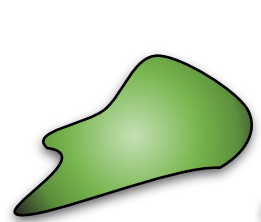

1971

98274

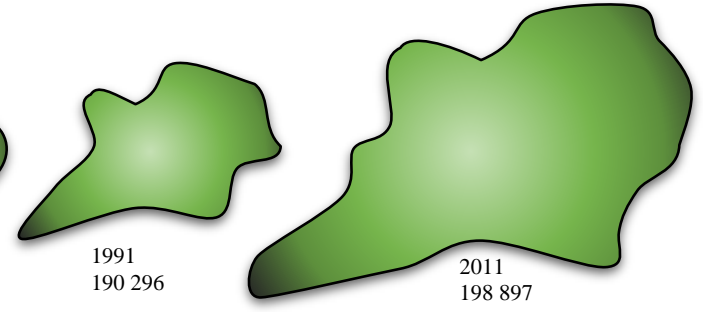

198897

Fig. 1. Spatial changes of land morphology and demography through decades, the city of Prishtina.

The research examines and presents the calculated data of air pollution according to the Air Quality Index, with statistical analysis: correlation, causation; a regression analysis between GDP and vehicle registration; and empirical research method using the daily measured values of air quality index, organized, classified, and adapted by the author, administered by the measured station and the equipment of the US Embassy in Prishtina, Kosovo. AQI presents numerically the level of the air quality, and what associated health effects might be a concern for public health. EPA calculates the AQI for five major air pollutants regulated by the Clean Air Act: ground-level ozone, particle pollution, carbon monoxide, sulphur dioxide, and nitrogen dioxide. For each pollutant, EPA has established national air quality standards to protect public health. Ground-level ozone and airborne particles are the two pollutants that pose the greatest threat to human health in this country [15]. An AQI value of 100, generally corresponds to the national air quality standard for the pollutant, which is the level that EPA has set to protect public health. AQI values below 100 are generally thought of as satisfactory. When AQI values are above 100, air quality is considered to be unhealthy for certain sensitive groups of people [15]. The data presented in Table 1, shows that the number of registered vehicles is increasing every year, especially in the last years, and there is the causal relationship to the urban health. The actual road framework in Prishtina, shows that the increasing numbers, age, and working conditions of the vehicles, low awareness of the consequences of air quality degradation, insufficient number of stations to measure the air quality, covering all key points, have increased significantly the air pollution in Prishtina [16].

TABLE 1. VehiCLE Registration OF Kosovo, 2011-2018 [16]

\begin{tabular}{lcccccccc}
\hline Vehicle type/ Years & $\mathbf{2 0 1 1}$ & $\mathbf{2 0 1 2}$ & $\mathbf{2 0 1 3}$ & $\mathbf{2 0 1 4}$ & $\mathbf{2 0 1 5}$ & $\mathbf{2 0 1 6}$ & $\mathbf{2 0 1 7}$ & $\mathbf{2 0 1 8}$ \\
\hline Cars & 170321 & 176398 & 222537 & 236145 & 281847 & 260291 & 273862 & 280422 \\
Transp. veh. $>\mathbf{3 . 5} \mathbf{~ M t}$ & 10877 & 11547 & 15352 & 15769 & 18330 & 17963 & 18559 & 33889 \\
Transp. veh. $<\mathbf{3 . 5} \mathbf{~ M t}$ & 17901 & 18225 & 24659 & 26949 & 30846 & 31285 & 32299 & 19371 \\
Van & 2698 & 2520 & 3225 & 3161 & 3212 & 2841 & 2535 & 2917 \\
Buses & 1117 & 1298 & 1570 & 1697 & 2124 & 1916 & 1949 & 2326 \\
Motorcycles & 546 & 809 & 1488 & 1540 & 1849 & 1790 & 1690 & 2038 \\
Tractors & 39 & 137 & 776 & 1036 & 941 & 613 & 523 & 1791 \\
Trailer $<\mathbf{3 . 5} \mathbf{M t}$ & 101 & 117 & 217 & 250 & 286 & 288 & 288 & 572 \\
Trailer > 3.5 Mt & 1766 & 1800 & 2283 & 2281 & 2707 & 2628 & 2735 & 305 \\
\hline Total: & $\mathbf{2 0 5 3 6 6}$ & $\mathbf{2 1 2 ~ 8 5 1}$ & $\mathbf{2 7 2 ~ 1 0 7}$ & $\mathbf{2 8 8 ~ 8 2 8}$ & $\mathbf{3 4 2} \mathbf{1 4 2}$ & $\mathbf{3 1 9 6 1 5}$ & $\mathbf{3 3 4} \mathbf{4 4 0}$ & $\mathbf{3 4 3 ~ 6 3 1}$ \\
\hline
\end{tabular}


The data from traffic measurements for the sustainable urban plan for future mobility in Prishtina, will help the municipal sectors in drafting strategic documents. In addition to these sectors, these data can also serve for the public companies operating in the Municipality of Prishtina. According to the Law on Spatial Planning no. 04 / L-174, the Directorate of Urbanism, states that: All spatial documents should be harmonized with the latest law. As a result of these legal requirements, the municipality of Prishtina has a good database of traffic data that can help in profiling new planned routes, modifying roads in new plans and adapting to a sustainable urban mobility plan where, alongside, it also sets the adjustment lines and the construction lines in the functional urban zones. From the research of plans in the thematic area of mobility and air pollution, we can conceptually conclude that mobility plans should implement the Urban Health environmental law acts. All possible irregularities are the result of the not adequate mobility policies. One of the issues of this nature are the roads near the railway station in Prishtina, which are designed incorporating tram tracks which run above and through the railway tracks. Building a tram network requires a lot of time to collect data at the city level and engage many professional experts. Thus, the existing road infrastructure in Prishtina has a limit to its ability in providing space for a new tram line. Eventually this could be possible, but only if one-way traffic is approved. As Table 1 indicates, in recent years vehicle registration in Kosovo has continued to increase and the main road arteries in Pristina are heavily overloaded. Priority should also be given to assessing the role of public urban transport, e-vehicle services, and further promotion of sustainable and ecological urban transport. The main actions for implementing these environment urban projects, requires heavy commitment, time, and financial means. Clearly, it is understandable that the municipality of Prishtina often goes through a process for the expropriation, or exchange of municipal and private properties for implementing these large projects, hence, such initiatives may also lead to conflicts in public opinion on these issues. For the case study the "Boulevard Bill Clinton" was observed, almost the same mentioned situation, which does not correspond to the factual situation. In an interval of 12 hours, 48000 vehicles travel on this boulevard in both directions. The traffic solution which is presented as a success story does not provide solving, since it is mainly designed to endure all heavy conditions, and in fact, this profile of road artery only offer the traffic jam. Therefore, by using the data provided by the traffic measurements in the city of Prishtina, there is a good opportunity to plan routes that suit the traffic load and actual situation, meet the needs of the urbanites, and those routes are integral part of the traffic infrastructure, and functional road flow network. The profile of most planned roads is almost similar to the profile of the existing actual state with some minor changes. According to the author Brauer, "Outdoor concentrations of traffic-related air pollutants (nitrogen dioxide $\mathrm{PM}_{2.5}$, particles with a $50 \%$ cut-off aerodynamic diameter of $2.5 \mathrm{~mm}$ and soot) were assigned to birthplace home addresses with a land-use regression model. They were linked by logistic regression to questionnaire data on doctor-diagnosed asthma, bronchitis, influenza and eczema and to self-reported wheeze, dry night-time cough, ear/nose/throat infections and skin rash. Traffic-related pollution was associated with respiratory infections and some measures of asthma, allergy during the first 4 yrs. of life" [17]. 
TABle 2. World Health ORganization (Who, 2006) Air Quality Guidelines (MG/M³) [18]

\begin{tabular}{llllll}
\hline Pollutant & Interim target 1 & Interim target 2 & Interim target 3 & Standard & Averaging Times \\
\hline $\mathbf{P M}_{2.5}$ & 35 & 25 & 15 & 10 & Annual \\
& 75 & 50 & 37.5 & 25 & 24-hour \\
$\mathbf{P M}_{\mathbf{1 0}}$ & 70 & 50 & 30 & 20 & Annual \\
& 150 & 100 & 75 & 50 & 24-hour \\
$\mathbf{O}_{3}$ & 160 & - & - & 100 & 8-hour \\
$\mathbf{N O}_{2}$ & - & - & - & 40 & Annual \\
& - & - & - & 200 & 1-hour \\
$\mathbf{S O}_{2}$ & 125 & - & - & 20 & 24-hour \\
& - & - & - & 500 & 10-minute \\
\hline
\end{tabular}

The current health condition and air pollution are main targeted objectives, as listed in Table 2, along with air quality standards and guidelines established by the World Health Organization, in addition to efforts focused on these major air pollutants, also concerned with toxic air pollutants that are less ubiquitous. These air pollutants include other hazard commixtures from motor vehicles, fuels, and coal combustion [18]. Empirically concluded, degraded urban health and air pollution emissions are expected to grow in Prishtina as a result of the increasing number of vehicles. Therefore, heavy traffic is among the main polluters of urban health in Prishtina, where the downtown represents foremost example case for investigation of urban health in relation to air quality. It is clear that urban health and air quality are indispensable. Obstacles in the urban transport, heavy traffic and illegal taxi operators significantly impede the sustainable development of urban public transport. However, the operation of urban public transport is economically viable with these capacities operating in Prishtina, whereas during weekends it is clear from visual observations and collected research data, the number of vehicles in traffic is significantly lower in both directions. The actual situation of traffic in Prishtina is humongous and problematic. The department of environmental protection in the Ministry of Environment and Spatial Planning estimates that the air quality trend in Kosovo is almost the same as in previous years, moreover, last year record values of air pollution have been identified, which means that during November and December there has been exceeded values for allowed pollution. The information desk and monitoring office at the Ministry of Environment and Spatial Planning states that the main sources of pollution are the production of energy, the use of fuels for heating and road traffic. The Ministry of Environment and Spatial Planning has drafted a plan of activities for the fall-winter season in 2017-2018. These actions, among other things, carry the final steps by identifying the main sources of pollution in Prishtina, proposing the concrete measures which have to be taken to mitigate the impact on air quality from these sources. According to the municipality, the biggest pollutants are: sulphur dioxide, nitrogen dioxide, and particles $\mathrm{PM}_{2.5}$, while the main cause of air pollution is heavy traffic, the use of fuels for heating, and the use of fuels in small businesses, mainly those of food preparation. Environmental municipality actions must include measures to increase air quality in Prishtina such as plans for the heavy traffic jam of vehicles, by promoting public and environmentfriendly transport, increasing the road network management efficiency, improving public 
vehicles, promoting clean technologies and promoting e-vehicles. Furthermore, the pollution may fall to lower levels even if fuel quality control is checked and if fuel-consuming businesses are controlled and obliged to be equipped with improved and contemporary technologies.

TABLE 3. COMPARISON OF GDP BETWEEN KOSOVO AND ITS NEIGHBOURING COUNTRIES, 2012-2019 [19]

\begin{tabular}{lccccccc}
\hline & \multicolumn{1}{c}{ Projections } \\
\cline { 2 - 7 } & 2012 & 2013 & 2014 & 2015 & 2019 & $\begin{array}{c}\text { Low/ } \\
\text { Annual Average (2020-2030) }\end{array}$ & $\begin{array}{c}\text { Medium/ } \\
\text { High }\end{array}$ \\
\hline Albania & 1.1 & 1.4 & 2.1 & 3 & 4.7 & $2.46 \%$ & $3.23 \%$ \\
Bosnia and & -1.2 & 2.5 & 0.4 & 1.5 & 4 & $1.79 \%$ & $2.46 \%$ \\
Herzegovina & -2.2 & -0.9 & -0.8 & 0.5 & 2 & $0.93 \%$ & $1.65 \%$ \\
Croatia & 2.8 & 3.4 & 2.5 & 3 & 4 & $2.70 \%$ & $3.60 \%$ \\
Kosovo & -0.4 & 2.7 & 3.5 & 3.5 & 4 & $2.89 \%$ & $3.84 \%$ \\
North Macedonia & -2.5 & 3.3 & 1.5 & 3.4 & 3 & $2.41 \%$ & $3.18 \%$ \\
Sentenegro & -1.5 & 2.6 & -2 & -0.5 & 3 & $1.11 \%$ & $1.83 \%$ \\
\hline
\end{tabular}

Table 3 shows GDP in Kosovo compared with the GDP of neighbouring countries. In 2014, Kosovo's GDP for capita was the second highest in the Western Balkans. According to the projections listed in Table 3, GDP during 2012-2019 in Kosovo shows a rise of $2.8 \%$ to $4 \%$. Actual figures for 2012-2013 and projections for 2014-2015 and 2019 are based on the International Monetary Fund, IMF 2014 [19]. In addition, the annual average projections for the timeline 2020-2030, are based and consulted with the World Bank organization. In this correlation, the National Institute of Public Health of Kosovo has conducted research on the effects of air pollution on the health of citizens of Prishtina where evidently there are a high number of patients from polluted air.

\section{Results}

The improvement of urban health, air quality, and the environment are among top urban priorities. According to the EU Directive for Air Quality (2008/50/EC it is permitted to exceed the standards values for $\mathrm{PM}_{10}$ for 35 days out of the year. Based on the data presented in Table 4 and illustrated in Fig. 2, there was a great exceedance in the values of $\mathrm{PM}_{2.5}$, indicated the amount of pollution from particulate matter in Prishtina, with the greatest excessive months being January, February, March, April, November and December. The assessment of $\mathrm{PM}_{2.5}$ concentrations in compliance with air quality standards is based on the annual value, therefore, in analysing dust pollution, standard values have exceeded, where the allowed rate is $25 \mu \mathrm{g} / \mathrm{m}^{3}$ during the year, with greatest excessive months: January, February, March, April, October, November and December (see Fig. 2). The largest cities in Kosovo, such as Prishtina, Gjilan, and Drenas, have heavy industrial and urban discharges. As such, those urban and spatial zones should be declared as zones with special environmental protection, because the hazard discharges in the environment are several times above the approved standards. In Prishtina, except $\mathrm{PM}_{10}$, and $\mathrm{PM}_{2.5}$, there are also other air polluters, 
such as: $\mathrm{CO}, \mathrm{NOx}, \mathrm{Pb}, \mathrm{Mg}, \mathrm{Zn}, \mathrm{Cr}, \mathrm{CO}_{2}$. Pollution from urban transport leads to water framework pollution also. Prishtina is commonly known for its shallow level of groundwater and the air polluted by the urban traffic, which contains heavy metals such as $\mathrm{Zn}, \mathrm{Pb}, \mathrm{Cd}, \mathrm{Cu}$, that stay in a suspended state for hours and arrive to close their cycle, states of aggregation, first settling on the soil or pedological area of the development of agricultural products, and then blend in the underground water. The framework and infrastructure of these waters are used for daily consumption or for city hygiene, resulting in hazard transformations that brought a great deal of damage to public health.

TABle 4. Measured VAlues For AQI, PM 2.5 IN Prishtina, 2017 [20]

\begin{tabular}{llll}
\hline $\begin{array}{l}\text { Per Month } \\
\text { PM2.5 }\end{array}$ & $\begin{array}{l}\text { Maximum } \\
\text { value of AQI }\end{array}$ & $\begin{array}{l}\text { Maximum amount } \\
\text { for } \mathbf{1} \text { hour, } \boldsymbol{\mu g} / \mathbf{m}^{\mathbf{3}}\end{array}$ & $\begin{array}{l}\text { Date of maximum value, } \\
\text { date }\end{array}$ \\
\hline January & 532 & 600 & 29.01 .2017 \\
February & 259 & 265 & 22.02 .2017 \\
March & 177 & 146 & 02.03 .2017 \\
April & 166 & 122 & 14.04 .2017 \\
May & 108 & 50 & 01.05 .2017 \\
June & 87 & 31 & 01.06 .2017 \\
July & 70 & 23 & 01.07 .2017 \\
August & 82 & 29 & 16.08 .2017 \\
September & 72 & 31 & 10.09 .2017 \\
October & 156 & 83 & 18.10 .2017 \\
November & 241 & 226 & 21.11 .2017 \\
December & 215 & 285 & 07.12 .2017 \\
\hline
\end{tabular}

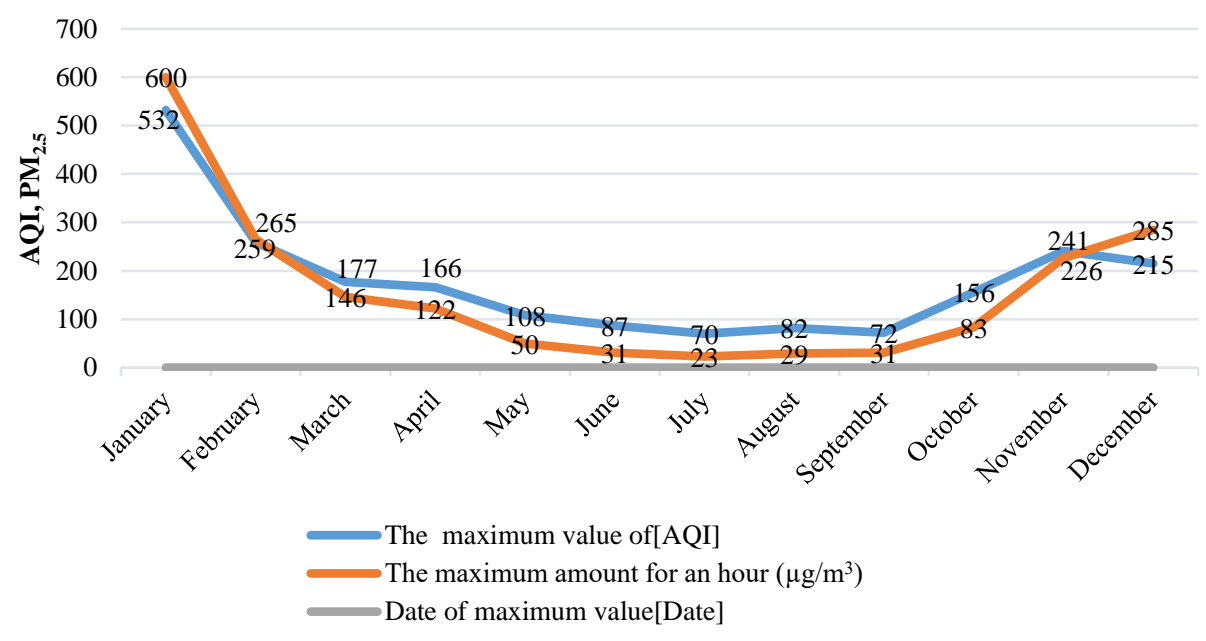

Fig. 2. Chart of measured values for AQI, $\mathrm{PM}_{2.5}$ in Prishtina, 2017. 
Based on the data presented in Table 5, there was an exceedance of $\mathrm{PM}_{2.5}$ values, indicated the amount of pollution from particulate matter in Prishtina, with greatest excessive months: January, February, March, April, September, October, November and December. The assessment of $\mathrm{PM}_{2.5}$, in analysing the dust pollution, standard values have been exceeded, also for 2018, during which, the greatest excesses months in relation to the $\mathrm{PM}_{2.5},\left[\mu \mathrm{g} / \mathrm{m}^{3}\right]$ was: January, February, March, October, November and December (see Fig. 3).

TABle 5. Measured VALUeS FOR AQI, PM2.5 IN PRISHTINA, 2018 [20]

\begin{tabular}{llll}
\hline $\begin{array}{l}\text { Per Month } \\
\mathbf{P M}_{2.5}\end{array}$ & $\begin{array}{l}\text { Maximum value } \\
\text { of AQI }\end{array}$ & $\begin{array}{l}\text { Maximum amount } \\
\text { for one hour, } \boldsymbol{\mu g} / \mathbf{m}^{\mathbf{3}}\end{array}$ & $\begin{array}{l}\text { Date of maximum } \\
\text { value, date }\end{array}$ \\
\hline January & 312 & 410 & 25.01 .2018 \\
February & 208 & 269 & 17.02 .2018 \\
March & 199 & 171 & 02.03 .2018 \\
April & 115 & 50 & 03.04 .2018 \\
May & 71 & 25 & 09.05 .2018 \\
June & 71 & 22 & 20.06 .2018 \\
July & 76 & 27 & 30.07 .2018 \\
August & 70 & 27 & 29.08 .2018 \\
September & 124 & 59 & 10.09 .2018 \\
October & 153 & 80 & 23.10 .2018 \\
November & 192 & 212 & 13.11 .2018 \\
December & 415 & 489 & 03.12 .2018 \\
\hline
\end{tabular}

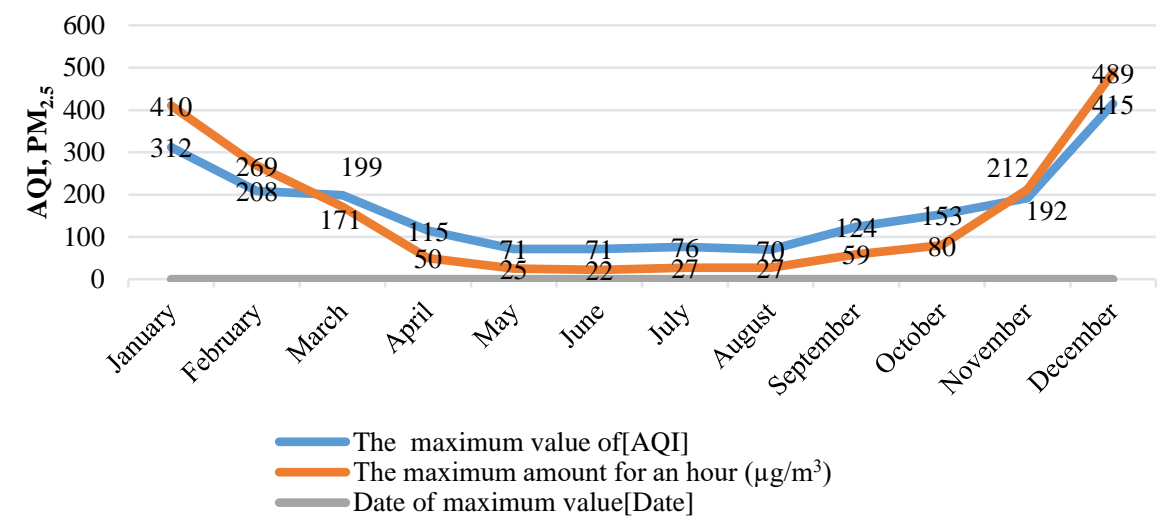

Fig. 3. Chart of measured values for AQI, $\mathrm{PM}_{2.5}$ in Prishtina, 2018.

\section{DiscuSSION}

The potentially polluting sources already known are: power plants, obsolete vehicles and dense traffic, burning fuels and solid fuels for heating, burning waste, lack of sufficient green areas, construction without proper urban planning, and huge dust presence in the urban 
communities. The basic objective of environmental protection is to achieve the following general goals in a manner that is both realistically affordable by public authorities, persons and undertakings and consistent with the sustainable economic development of Kosovo:

1. Environmental control of air filters in power plants over 24 hours, quality fuels and fuel consumption used for heating;

2. Promotion and use of buses with ecological fuels as public transport;

3. Limiting of the number of vehicles being driven from the suburbs into the capital, promoting parking garages located at the second urban ring of the capital as public parking points;

4. Urgent environmental control of vehicles and banning those that do it comply with environmental standards;

5. Permanent measurement of air pollution at key points in Prishtina with online results;

6. Use of protective urban masks by persons suffering from respiratory diseases;

7. Endangered population groups such as those with chronic pulmonary, heart, asthmatic and prone patients for allergies, the elderly, young children, pregnant women, shall be recommended to stay indoors when air pollution hazards prevail.

According to the EPA, as listed in Table 6, each category corresponds to a different level of health concern. The six levels of health concern means are: AQI is 0-50, air quality is considered satisfactory, and air pollution poses little or no risk. When AQI is 51-100, air quality is acceptable. Although general public is not likely to be affected at AQI range 101150 , people with lung disease, older adults and children are at a greater risk. If AQI is $151-$ 200 , everyone may begin to experience some adverse health effects, and members of the sensitive groups may experience more serious effects. When AQI is 201-300, this would produce a health alert signifying that everyone may experience more serious health effects, and AQI greater than 300 would produce a health warning of emergency conditions, and surely the entire population is more likely to be affected [20].

Table 6. Values of AQI, LeVels of Health Concern, AdAPted [20].

\begin{tabular}{lll}
\hline Air Quality Index & $\begin{array}{l}\text { Numerical Value } \\
\text { AQI }\end{array}$ & Meaning \\
\hline Good & 0 to 50 & $\begin{array}{l}\text { Air quality is considered satisfactory, and air pollution poses } \\
\text { little risk. } \\
\text { Air quality is acceptable; however, for some pollutants there } \\
\text { may be a moderate health concern for a very small number of } \\
\text { people who are unusually sensitive to air pollution. }\end{array}$ \\
Moderate & 51 to 100 & $\begin{array}{l}\text { Members of sensitive groups may experience health effects. } \\
\text { The general public is not likely to be affected. }\end{array}$ \\
$\begin{array}{l}\text { Unhealthy for } \\
\text { Sensitive Groups }\end{array}$ & 101 to 150 & $\begin{array}{l}\text { Everyone may begin to experience health effects; members of } \\
\text { sensitive groups may experience more serious health effects. }\end{array}$ \\
Unhealthy & 151 to 200 & $\begin{array}{l}\text { Health alert: everyone may experience more serious health } \\
\text { effects. } \\
\text { Very Unhealthy }\end{array}$ \\
Hazardous & 201 to 300 & $\begin{array}{l}\text { Health warning of emergency conditions. The entire population } \\
\text { is more likely to be affected. }\end{array}$ \\
\hline
\end{tabular}

The research carried out by the National Public Health Institute in Prishtina, presented the findings according to the tenth international classification (SNC 10)-2015, in the morbidity of the Primary Health Care, the largest number of diseases recorded is that of group X (respiratory diseases with 156672 cases or $(31.1 \%)$ then group XI (Diseases of the digestive 
system with 69293 cases or $(13.8 \%)$. The lowest participation is in the group XVI (Certain conditions derived from the perinatal period) with 172 cases or $(0.01 \%)$. In the causal relationship to the research carried out in 2016, the findings are: in the morbidity of the Primary Health Care, the largest number of diseases recorded is that of group X (Respiratory, Ventilation ailments with 142357 cases $(32.58 \%)$ followed by group XI (Diseases of the digestive system with 57941 cases $13.26 \%$. The lowest participation is in the group of XVI (Certain conditions derived from the perinatal period) with 161 cases $(0.03 \%)$ [21]. Coal handling and grinding processes are correlated with powerful environment pollution, with fine dust ejection into the ambient. The problem is especially critical when a coal-fired power plant, and coal processing company is located in a vicinity of massively populated city, such is the case of the city of Prishtina [22]. "Chronic respiratory diseases (CRDs) are diseases of the airways and other structures of the lung. Some of the most common ones are chronic obstructive pulmonary disease (COPD), asthma, occupational lung diseases and pulmonary hypertension. In addition to tobacco smoking, other risk factors include air pollution, occupational chemicals and dusts, and frequent lower respiratory infections during childhood" [23]. "Outdoor air pollution is large and increasing a consequence of the inefficient combustion of fuels for transport, power generation and other human activities like home heating and cooking. Combustion processes produce a complex mixture of pollutants that comprises of both primary emissions, such as diesel soot particles and lead, and the products of atmospheric transformation, such as ozone and sulphate particles. In 2012, ambient air pollution was responsible for 3 million deaths worldwide, and 169250 child deaths under five." [24]. Furthermore, energy is crucial and essential for all human activities, especially when the governments apply the efficiency environmental action plans regarding to the public health [25]. Public health cannot be achieved only regionally, environmental actions are crucially necessary, but again, only through overall global activities we can await the needed outcome of improved health and environmental conditions. In this study, we contend that there is no substitute or recompense to the health, hence, the actual state of energy production is not the most effective pathway to the stability for basic load of energy [26], [27].

TABle 7. TRees that CAN Reduce Air Pollution [28]

\begin{tabular}{|c|c|c|c|c|c|c|c|}
\hline Trees & $\begin{array}{l}\text { Height, } \\
\text { m }\end{array}$ & $\begin{array}{l}\mathrm{CO}_{2} \text { stored } \\
\text { 30/yr. City, } \\
\mathrm{Mt}\end{array}$ & $\begin{array}{l}\mathrm{CO}_{2} \\
\text { stored } \\
\text { 50/yr. } \\
\text { Park, Mt }\end{array}$ & VOC & $\begin{array}{l}\text { Ozone } \\
\text { format. } \\
\text { potential }\end{array}$ & $\begin{array}{l}\text { Potential } \\
\text { for } \\
\text { absorption } \\
\text { of gas. pollut. }\end{array}$ & $\begin{array}{l}\text { Potential } \\
\text { for capturing } \\
\text { dust }\end{array}$ \\
\hline & & & & \multicolumn{4}{|c|}{ Ability to environmental mitigation potential } \\
\hline $\begin{array}{l}\text { Acer } \\
\text { Platanoides }\end{array}$ & 25 & 4.807 & 6.601 & Low & Low & High & Med. \\
\hline $\begin{array}{l}\text { Tilia } \\
\text { Platyphyllos }\end{array}$ & $>25$ & 3.660 & 5.070 & Med. & Aver. & High & High \\
\hline Tilia Cordata & $15-25$ & 3.660 & 5.070 & Low & Low & High & High \\
\hline
\end{tabular}

In correlation to the urban health and air quality, there are also environmental ecological urban measures, according to the research of GAIA, "The tree species used for the GAIAurban forestation project were selected, starting from the green Regulations of the City of Bologna and evaluating important factors such as the potential for absorption of pollutants $\left(\mathrm{CO}_{2}\right.$ and $\left.\mathrm{PM}_{10}\right)$, the release of substances volatile and the allergenic specific factors, the first 24 most suitable species have been identified to fulfil this function" [28]. As listed in Table 7 
and depicted in Fig. 4, "there is a considerable potential to further develop the beneficial use of vegetation to promote urban environmental quality and citizen health. Trees and shrubs were compared for PM accumulation on the surface" [29].

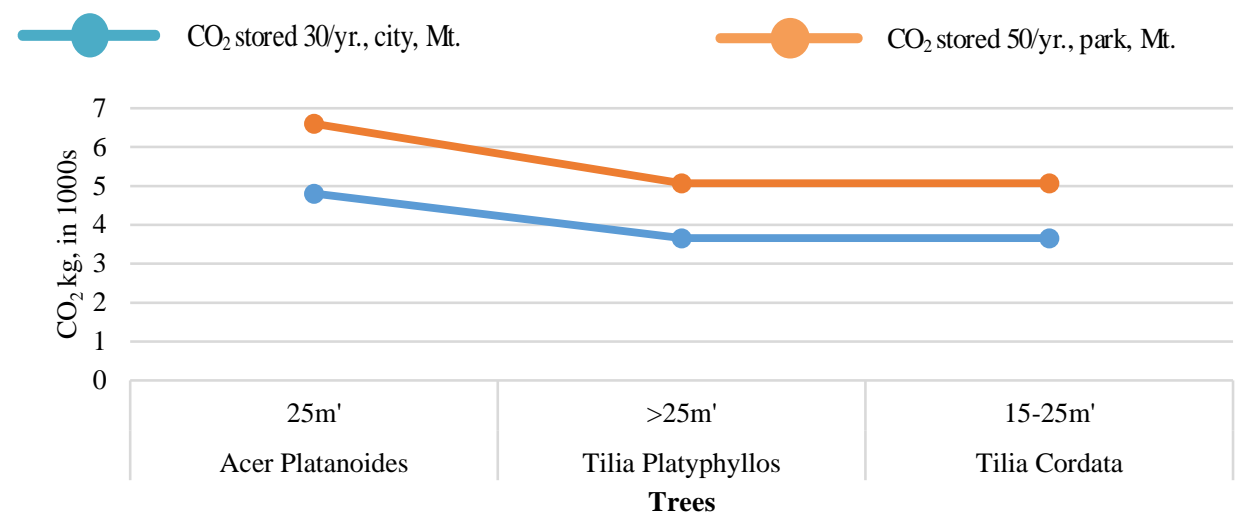

Fig. 4. Trees that can reduce air pollution.

With climate change widely witnessed, and the impact of products that actually consume energy during use [30], we cannot afford to use more energy than we need. Today $40 \%$ of total energy consumption in the European Union comes from the building sector [31], [32]. In addition to the energy use, related to the traffic vehicles, Kosovo has raised its traffic level, approximately 342000 vehicles, registered in 2015 or $18.46 \%$ more than in 2014 [33]. Therefore, traffic is among the main polluters of air in Prishtina, whereas the capital of Kosovo represents foremost this phenomenon of urban planning in relation to air pollution. It is expected that adopted measures according to the Strategy of Action Plan on Air Quality from Ministry of Environment and Spatial Planning to carry out some positive impact, such as: "Restricted access to polluted urban areas for vehicles with high pollution ... Determination of space in the city centre areas with high pollution from traffic, where access is prohibited" [34]. According to the GAP Institute, the Air Quality Strategy 2013-2021 identifies several sources as the main pollutants of the air. However, the strategy is inconsistent, general and unclear. The strategy identifies the potential sources of air pollution by listing the following sources: power plants Kosovo A and Kosovo B, lignite surface mines, industrial complexes in Mitrovica, Ferronikeli in Drenas, Sharcem cement factory in Hani i Elezit, central heating systems in Prishtina, Gjakova and Mitrovica, the production of asphalt bases, transport, agriculture. However, other small sources or "individual heating facilities" are missing from this list. Furthermore, this state of expertise speaks of a serious lack of consistency in the fundamental and crucial key points, identifying the main pollutants [35]. For instance, this strategy states "The average consumption of wood for household purposes is $9.7 \mathrm{~m}^{3}$ a year", while a sentence later it stated according to the data until 2007, it is estimated that the consumption of wood for household needs is $2.41 \mathrm{~m}^{3}$ per year.

Generally, the best way to solve a problem is to diagnose its source; in the case of air pollution, it is of key importance to identify the major pollutants. Only after the largest pollutants have been identified, measures that will have an impact on reducing air pollution can be applied. In relation to the main pollutants, power plants Kosovo-A and Kosovo-B often categorized as the largest polluters in Kosovo, are the first to come to conclusion when it 
comes to air pollution. However, although coal production is responsible for a large part of air pollution in general, it does not play much role in pollution seasonality. Also, the temperature inversion phenomenon plays a key role in creating smog and hold up pollutants in the atmosphere. As a consequence of this temperature inversion, pollutants are much more difficult to disperse into the atmosphere, thus, strengthened with the lack of steady winds, rainfall, and the presence of mountains around the settlement make the inversion stronger, and as a result, the air quality is getting worse [35]. According to the MESP, the Air Quality Strategy sets targets for air quality and alternative policies for further improving air quality that will provide significant benefits in improving the quality of life and helping to protect the environment and sustainable development. The objectives and measures identified in this research for each sector are also aimed at establishing a guideline for Air Quality Action Plan. For each sector that is responsible for air pollution, specific objectives and measures must be defined, resulting in reduction of air pollution. Furthermore, the highest priority set by the emerging measures is the building of the most effective air quality management system [36]. Although air strategy guidelines must be in line with EU Directives, there will certainly be a need to re-examine air quality in the future in order to follow up on changes that may be made in EU directives. Therefore, actions should include: Promoting air quality activities and crucially encouraging the reduction of emissions by vehicles, strengthen environmental activities and healing environmental strategies, thus, encouraging of public e-transport, defining the new bicycle trails, improvement of the existing public transport services, and road infrastructure quality. We must be very clear that public actions are needed to promote the change of social behaviour generally, focusing on public awareness that we must contribute as society to reduce emissions locally which will have an impact globally. There is no doubt that urban health and sensitization for air quality raise the public's awa reness, which helps in addressing key issues by raising the government's attention to provide a strategic and quality ecological initiatives for the communities in the future, surely, those actions must be interdependent with global environmental organizations, world scientific institutions, non-government organizations, also, being in line of possibilities and awareness of limited environmental budget of Kosovo. Surely, environmental activities have holistic approach, having always ecological impact wider than the concerned area. Visualisation for strategy of healing urban health in Prishtina depicted in Fig. 5.

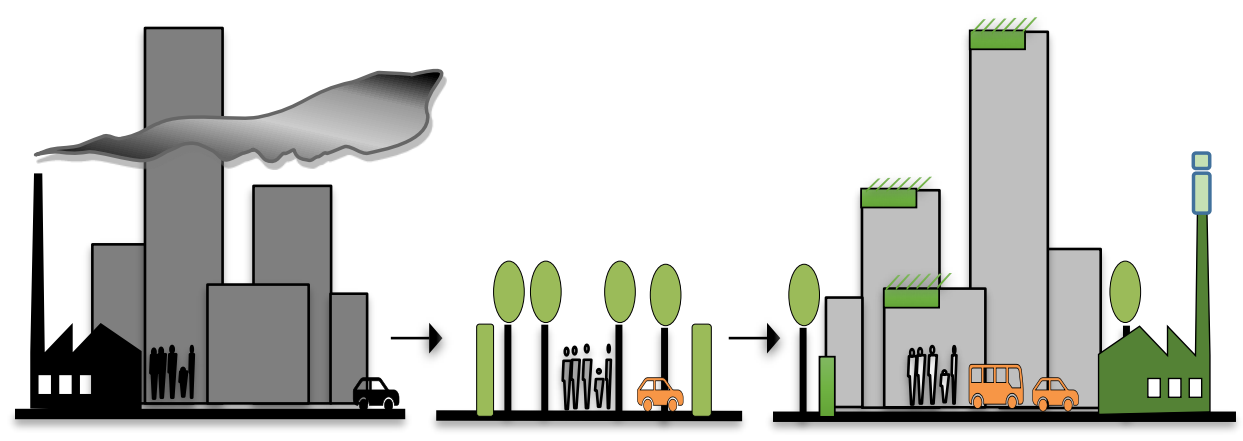

Fig. 5. Prishtina, urban vegetation health protection measures, and healing urban strategies. 


\section{CONCLUSION}

The use of coal in power generation and heating, Power Plants Kosovo-A, and Kosovo-B, transport energy production sector, and heavy traffic are the main pollutants, and as such have a major role in overall air pollution. Moreover, if the role of temperature inversion is too great, then, it means that the air pollution is much greater. However, what the research findings suggest is that the heating sector is also a very important sector in air pollution [37]. Furthermore, the increase of the meteorological conditions in correlation with the use of wood and coal for heating contributes to the growth of pollutants with serious consequences for the health of citizens. Air pollution is a global issue; therefore, it cannot be addressed solely locally, moreover coordinated global and local actions are irreplaceable and crucially necessary [38]. The current regression state of urban health and urban fabric in Prishtina, requires specific responsibilities and activities, especially when the state is directly linked to the quality of life of young generations. Prishtina, like other cities must immediately consider to implement a strategy of healing urban health, strengthened by the new contemporary technologies, actions that promote and focus on expected health hazards with serious devastating implications, and environmental day to day crucial healing actions.

\section{REFERENCES}

[1] Bajçinovci B. Q. Challenges of Architectural Design in relation to Environment and Air Pollution. A Case study: Prishtina's first public parking garage. Journal of Science, Humanities and Arts 2016:3(7). https://doi.org/10.17160/josha.3.7.254

[2] U.S. Department of Energy. Greening Federal Facilities. An Energy, Environmental, and Economic Resource Guide for Federal Facility Managers and Designers $2^{\text {nd }}$ ed. Wilson A. (Eds). Vermont: BuildingGreen, Inc., 2001.

[3] Fernandez-Armesto F. Civilizations: Culture, ambition, and the transformation of nature. New York: Touchstone, 2002.

[4] De Oliviera, L., F., Mell, I. (Eds). Planning Cities with Nature Theories, Strategies and Methods. Springer, Cham 2019:193. https://doi.org/10.1007/978-3-030-01866-5

[5] UN Habitat. Urbanization and development: emerging futures. World cities report 2016. Nairobi, 2016.

[6] Simon J. S. Protecting Clean Air: Preventing Pollution. New York: Momentum Press LLC, 2018.

[7] Bhave V. P. et al. Source Apportionment of Primary Carbonaceous Aerosol Using the Community Multiscale Air Quality Model. In Air Pollution Modeling and Its Application XVII. (Eds). Borrego, C., Norman, A., L. New York, 2007.

[8] The National Academy of Sciences, US. Global Sources of local pollution. An Assessment of Long-Range Transport of Key Air Pollutants to and from the United States. Washington: The National Academies Press, 2010.

[9] WHO. Health effects of transport-related air pollution, Krzyzanowski et al. (Eds). Copenhagen: Regional Office for Europe, 2005.

[10] Kabashi S. et al. Effects of Kosovo's energy use scenarios and associated gas emissions on its climate change and sustainable development. Applied Energy 2011:88(2):473-478. https://doi.org/10.1016/j.apenergy.2010.06.023

[11] Kabashi S. et al. Greenhouse gas and air pollution emissions and options for reducing from the Kosovo transportation sector-dynamic modelling. Management of Environmental Quality 2001:22(1):72-88. https://doi.org/10.1108/14777831111098499

[12] Capello F., Gaddi V. A. (Eds). Clinical Handbook of Air Pollution-Related Diseases. Springer, Cham 2018. https://doi.org/10.1007/978-3-319-62731-1

[13] Salthammer T., Uhde E. (Eds). Organic Indoor Air Pollutants. Occurrence, Measurement, Evaluation $2^{\text {nd }}$ ed. WILEYVCH Verlag GmbH \& Co. KGaA, Weinheim, 2009.

[14] Schwela D. et al. Urban Air Pollution in Asian Cities. Status, Challenges and Management. Earthscan, Stockholm Environment Institute and the Clean Air Initiative for Asian Cities, 2006.

[15] EPA. Environmental Protection Agency, US Air Quality Index, 2019. [Online]. [Accessed 16.03.2019]. Available: https://airnow.gov/index.cfm?action=aqibasics.aqi

[16] KAS. Ministry of Infrastructure, Roads Directorate. Kosovo Agency of Statistics, 2018.

[17] Brauer M. et al. Air pollution and development of asthma, allergy and infections in a birth cohort. European Respiratory Journal 2007:29:879-888. https://doi.org/10.1183/09031936.00083406 
[18] National Academy of Engineering and National Research Council. Energy Futures and Urban Air Pollution Challenges for China and the United States. Washington, D.C.: The National Academies Press. 2008.

[19] IMF. World Economic Outlook 2014: Legacies, Clouds, Uncertainties. International Monetary Fund, 2014. [Online]. Available: www.imf.org/external/pubs/ft/weo/2014/02/pdf/text.pdf

[20] Environmental Protection Agency. AirNow, 2019. [Online]. [Accessed 16.03.2019]. Available: https://airnow.gov/index.cfm?action=airnow.global_summary\#Kosovo\$Pristina

[21] National Public Health Institute in Prishtina, Kosovo. Morbidity analysis for the 2015, 2016 of the Primary Health Care Services in Kosovo, 2018. [Online]. Available: http://niph-rks.org/?lang=en

[22] Silinš K., Žandeckis A., Valtere S. Determination of Solid Particle Concentration at Coal Transshipment Site. Environmental and Climate Technologies 2010:3(3):97-101. https://doi.org/10.2478/v10145-009-0013-8

[23] WHO, 2018. Chronic respiratory diseases. [Online]. Available: https://www.who.int/respiratory/en/

[24] WHO, 2018. Children's environmental health. [Online]. Available: https://www.who.int/ceh/risks/cehair/en/

[25] Asere L., Blumberga A. Government and municipality owned building energy efficiency system dynamics modelling. Energy Procedia 2015:72:180-187. https://doi.org/10.1016/j.egypro.2015.06.026

[26] Bariss U., Bazbauers G., Blumberga A., Blumberga D. System Dynamics Modeling of Households' Electricity Consumption and Cost-Income Ratio: A Case Study of Latvia. Environmental and Climate Technologies 2017:20:3650. https://doi.org/10.1515/rtuect-2017-0009

[27] Blumberga A., Timma L., Blumberga D. System Dynamic Model for the Accumulation of Renewable Electricity using Power-to-Gas and Power-to-Liquid Concepts. Environmental and Climate Technologies 2016:16:54-68. https://doi.org/10.1515/rtuect-2015-0012

[28] GAIA, Institute of Biometeorology, Bolonia. Baraldi, R., European Life+ project. Trees that can reduce air pollution. 2016. [Online]. Accessed: 24.08.2016. Available: http://lifegaia.eu/

[29] Saebo A. et al. Characterization of urban trees and shrubs for particulate deposition, carbon sequestration and BVOC emissions. Acta Hortic 2013:990:509-517. https://doi.org/10.17660/ActaHortic.2013.990.66

[30] European Parliament and Council Directive 2010/31/EU on building energy efficiency. The Official Journal of the European Union 2010:153:13-35.

[31] EEA. Final energy consumption by end use in the EU-27. [Online]. [Accessed: 24.08.2018.]. Available: www.eea.europa.eu/data-and-maps/indicators/energy-efficiency-and-energy-consumption-5/assessment/

[32] Biseniece E., Freimanis R., Purvins R., Gravelsins A., Pumpurs A., Blumberga A. Study of Hygrothermal Processes in External Walls with Internal Insulation. Environmental and Climate Technologies 2018:22:22-41. https://doi.org/10.1515/rtuect-2018-0002

[33] Kosovo Agency of Statistics. Transport and telecommunications statistics TM2-2016, 2016. [Online]. [Accessed: 12.08.2016]. Available: http://ask.rks-gov.net/sq/transporti

[34] Ministry of Environment and Spatial Planning. Strategy and Action Plan on Air Quality. Kosovo, 2011. [Online]. [Accessed: 19.08.2016].

Available: http://www.kryeministriks.net/repository/docs/Strategy_and_Action_Plan_on_Air_Quality.pdf

[35] GAP, Institute. Causes of air pollution in Prishtina. [Online]. [Accessed: 17.09.2018]. Available: http://www.institutigap.org/documents/69660_ShkaqeteNdotjesseAjritnePrishtine.pdf

[36] MESP, Ministry of Environment and Spatial Planning. Air Quality Strategy in Kosovo. [Online]. [Accessed: 17.09.2018]. Available: https://goo.gl/bSdnX6

[37] Bajçinovci B., Jerliu F. Achieving Energy Efficiency in Accordance with Bioclimatic Architecture Principles. Environmental and Climate Technologies 2016:18:54-63. https://doi.org/10.1515/rtuect-2016-0013

[38] Bajçinovci B. Environment Quality: Impact from Traffic, Power Plant and Land Morphology, a Case Study of Prishtina. Environmental and Climate Technologies 2017:19:65-74. https://doi.org/10.1515/rtuect-2017-0006

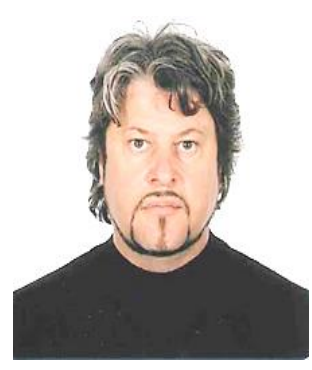

Bujar Bajçinovci Dr. Sc. Ing. Received Dr degree on Technical Sciences in the field of architecture and urbanism, Faculty of Architecture, University of Sarajevo, BiH (2012). He holds a position of assistant professor of the architectural design in University of Prishtina, Kosovo. His research interests focus on the field of sustainable architectural design, energy efficiency, renewable energy in building sector, and environmental pollution. He is the author of more than 7 scientific publications, indexed in SCOPUS and WOS, the author of more than 40 scientific publications indexed in relevant scientific databases, a confirmed reviewer of more than 3 research papers, and author of 10 scientific monographs. Membership: International Academy of Sciences, Humanities and Arts. IASHA. Assistant editor of the Journal of Sciences, Humanities and Arts, JOSHA. Member of the Editorial Board of the journal Pollution Research. Member of the Editorial Board of the journals: Ecology, Environment and Conservation.

E-mail: bujar.bajcinovci@uni-pr.edu

Researcher ID: Y-3401-2018, https://publons.com/author/1596832/

ORCID iD: https://orcid.org/0000-0003-1494-6633 


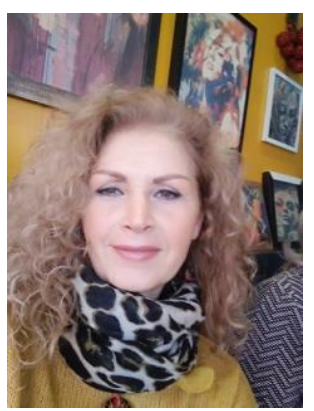

Mejreme Bajçinovci is a Medical Doctor and Public Health Specialist. She currently works at the National Public Health Institute in Prishtina, Kosovo. Her main activities and responsibilities at the institute are management, organization, planning, programming, promotion, and supervision of Public Health. From 1999-2000 she was the Public Health Supervisor - creating Health materials and messages (mass media) IRC (International Rescue Comity), and Health Promotion. From 2000-2001 she was the National trainer on Health Promotion, organization, programming, training, supervision at WHO (World Health Organization) Office in Kosovo, also on Health Promotion. From 1994-1999 she was MD, at the NGO Mother Teresa in Prishtina. She is the author of two scientific publications and she attended and published in more than 32 international conferences. Moreover, she is a certified Public Health Specialist at the Chamber of MD in Kosovo.

E-mail: mirebaj@yahoo.com 